\title{
Teaching an old pET new tricks: tuning of inclusion body formation and properties by a mixed feed system in E. coli
}

\author{
David J. Wurm ${ }^{1}$ • Julian Quehenberger ${ }^{1}$. Julia Mildner ${ }^{1} \cdot$ Britta Eggenreich $^{1}$ • \\ Christoph Slouka $^{1,2} \cdot$ Andreas Schwaighofer $^{3} \cdot$ Karin Wieland $^{3} \cdot$ Bernhard Lendl $^{3}$. \\ Vignesh Rajamanickam ${ }^{1,2} \cdot$ Christoph Herwig ${ }^{1,2} \cdot$ Oliver Spadiut $^{1}$ (B)
}

Received: 11 September 2017 / Revised: 6 November 2017 / Accepted: 7 November 2017 / Published online: 20 November 2017

(C) The Author(s) 2017. This article is an open access publication

\begin{abstract}
Against the outdated belief that inclusion bodies (IBs) in Escherichia coli are only inactive aggregates of misfolded protein, and thus should be avoided during recombinant protein production, numerous biopharmaceutically important proteins are currently produced as IBs. To obtain correctly folded, soluble product, IBs have to be processed, namely, harvested, solubilized, and refolded. Several years ago, it was discovered that, depending on cultivation conditions and protein properties, IBs contain partially correctly folded protein structures, which makes IB processing more efficient. Here, we present a method of tailored induction of recombinant protein production in E. coli by a mixed feed system using glucose and lactose and its impact on IB formation. Our method allows tuning of IB amount, IB size, size distribution, and purity, which does not only facilitate IB processing, but is also crucial for potential direct applications of IBs as nanomaterials and biomaterials in regenerative medicine.
\end{abstract}

Keywords Escherichia coli BL21(DE3) · pET expression system · Lactose · Inclusion body properties · Inclusion body size · Inclusion body purity

\section{Introduction}

Escherichia coli is the most widely used host organism for recombinant protein production due to its well-studied genome, the existence of numerous cloning vectors and engineered strains, as well as the possibility of cheap and straight-forward cultivation to high cell densities yielding high

Julian Quehenberger and Julia Mildner contributed equally to this work.

Electronic supplementary material The online version of this article (https://doi.org/10.1007/s00253-017-8641-6) contains supplementary material, which is available to authorized users.

Oliver Spadiut

oliver.spadiut@tuwien.ac.at

1 Research Division Biochemical Engineering, Institute of Chemical, Environmental and Biological Engineering, TU Wien,

Vienna, Austria

2 Christian Doppler Laboratory for Mechanistic and Physiological Methods for Improved Bioprocesses, Institute of Chemical, Environmental and Biological Engineering, TU Wien, Vienna, Austria

3 Institute of Chemical Technologies and Analytics, TU Wien, Vienna, Austria product titers (Choi et al. 2006; Huang et al. 2012; Joseph et al. 2015; Liu et al. 2015). As generally known, a careful balance between transcription and protein folding must be realized to increase the amount of soluble product (SP) in $E$. coli. If the folding machinery gets overwhelmed, correctly folded secondary structures cannot be formed and inclusion bodies (IBs) are produced (e.g., (Gatti-Lafranconi et al. 2011; Marschall et al. 2016)). In this respect, induction temperature, $\mathrm{pH}$ of the cultivation medium, and changes in the amino acid sequence of the product have a profound effect (Strandberg and Enfors 1991).

The by far most used E. coli strain is E. coli BL21(DE3) as it is known for a reduced amount of proteases and prevented plasmid loss (Jia and Jeon 2016; Liu et al. 2015; Rosano and Ceccarelli 2014). This strain is mostly used in combination with the T7-based $\mathrm{pET}$ expression system, which is usually induced by isopropyl- $\beta$-D-thiogalactopyranoside (IPTG), a nonmetabolizable molecular mimic of allolactose, known for strong induction (Bashir et al. 2016; Durani et al. 2012; Jia and Jeon 2016; Marbach and Bettenbrock 2012; Rosano and Ceccarelli 2014; Wurm et al. 2016). However, IPTG puts a high metabolic burden on E. coli (Dvorak et al. 2015; Haddadin and Harcum 2005), and thus causes the enhanced formation of IBs 
(Sina et al. 2015; Zhang et al. 2015). For a long time, IBs were considered to be aggregates of misfolded and inactive product, which is why IB formation was highly undesired for decades (Baneyx 1999; Choi et al. 2006; Marston 1986). However, in the past few years, IBs were found to have many advantages, such as significantly higher primary yields, simple separation from cell matter, high purity, and resistance to proteolysis (Choi et al. 2006; Ramon et al. 2014; Yamaguchi and Miyazaki 2014). Consequently, marketed biopharmaceuticals from E. coli, such as hormones, growth factors, interleukins, and insulin, are nowadays mostly produced as IBs, followed by solubilization and refolding to get soluble target product (Eiberle and Jungbauer 2010; Schmidt 2004; Yamaguchi and Miyazaki 2014).

Furthermore, it was found that, depending on cultivation conditions, IBs contain correctly folded secondary structures (Gatti-Lafranconi et al. 2011). The presence of such structures actually allows a comparably mild treatment during IB processing to maintain the already correctly folded secondary structures and thus increase the refolding yield. Different products, such as granulocytecolony stimulating factor, truncated forms of tumor necrosis factor, lymphotoxin $\alpha$, and the marker protein green fluorescent protein, have already been successfully produced by that strategy (Jevsevar et al. 2005; Peternel et al. 2008a, b; Singh et al. 2015b; Villaverde et al. 2015).

However, most of the current recombinant protein production processes with $E$. coli still aim at the production of SP instead of IBs. In this respect, several approaches for tuning recombinant protein expression in BL21(DE3) and thus, the level of SP and IB have been proposed. While many studies suggest suboptimal growth conditions to slow down all cellular processes, including transcription and translation (Peternel and Komel 2011; Vera et al. 2007), others propose supplying limiting amounts of IPTG (below $1 \mu \mathrm{mol}$ IPTG/g biomass) to tune down transcription (Striedner et al. 2003). In this respect, we used lactose as inducer instead of IPTG in previous studies (Wurm et al. 2017; Wurm et al. 2016), as it enhances correct protein folding and increases cell fitness (Bashir et al. 2016; Fruchtl et al. 2015; Ma et al. 2013; Wurm et al. 2016). We demonstrated that actually both SP titer and IB titer were influenced by the specific uptake rate of lactose $\left(q_{\mathrm{s} \text {,lac }}\right)$, which in turn depends on the specific uptake rate of glucose $\left(q_{\mathrm{s}, \mathrm{glu}}\right.$; (Wurm et al. 2016, 2017)). We generated a mechanistic model (Wurm et al. 2016, 2017) for this delicate balance between ATP-related uptake of lactose at low $q_{\mathrm{s}, \mathrm{glu}}$ (Johnson and Brooker 2004; Kaback 2015) and carbon catabolite repression at high $q_{\mathrm{s}, \mathrm{glu}}$ ((Bruckner and Titgemeyer 2002; Kremling et al. 2015; Warner and Lolkema 2003); Supplementary Fig. S1).

In this follow-up study, we investigated the correlation between $q_{\mathrm{s} \text {, lac }}$ and IB formation in more detail. For this purpose, we decoupled growth and induction by keeping $q_{\mathrm{s}, \mathrm{glu}}$ constant and applying different $q_{\mathrm{s} \text {,lac }}$ to potentially vary IB titer and properties. Motivated by a study of Peternel et al., who showed that IB properties strongly depend on cultivation conditions (Peternel et al. 2008b), we hypothesized that not only the amount of IBs, but also IB properties can be tuned by adjusting different $q_{\mathrm{s}, \text { lac }}$ and thus different levels of induction. Furthermore, we analyzed the effects of these conditions on the expression of SP to retrieve information about the total expression capacity of $E$. coli. For this purpose, we used the model protein enhanced green fluorescence protein (eGFP), which is a representative of the beta-barrel protein class and prominent for protein quality studies.

\section{Materials and methods}

\section{Strain}

For all experiments, E. coli BL21(DE3) (Life technologies, Carlsbad, CA, USA), transformed with a pET21a(+) vector carrying the gene coding for enhanced green fluorescent protein (eGFP) was used as expression host.

\section{Bioreactor cultivations}

All fermentations comprised a batch cultivation followed by an uninduced fed-batch for biomass generation and a $12 \mathrm{~h}$ induction phase. Experiments were carried out in DASbox ${ }^{\circledR}$ Mini Bioreactors (Eppendorf, Hamburg, Germany) with a working volume of $250 \mathrm{~mL} . \mathrm{CO}_{2}$ and $\mathrm{O}_{2}$ in the off-gas were analyzed by a DASGIP ${ }^{\circledR}$ GA gas analyzer (Eppendorf, Hamburg, Germany); $\mathrm{pH}$ by a $\mathrm{pH}$-Sensor EasyFerm Plus (Hamilton, Reno, NV, USA); and dissolved oxygen $\left(\mathrm{dO}_{2}\right)$ by a Visiferm DO 120 electrode (Hamilton, Reno, NV, USA). $\mathrm{dO}_{2}$ was kept above $40 \%$ oxygen saturation throughout the whole fermentation by supplying $2 \mathrm{vvm}$ of a mixture of pressurized air and pure oxygen. Biomass concentration was estimated using a soft-sensor-tool (Wechselberger et al. 2013), feed-flowrates were adjusted with the DASbox ${ }^{\circledR}$ MP8 Multi Pump Module, $\mathrm{pH}$ was kept at 7.2 by supplying $12.5 \%$ $\mathrm{NH}_{4} \mathrm{OH}$, stirring speed was set to $2000 \mathrm{rpm}$, and temperature was set to $35^{\circ} \mathrm{C}$ during batch and fed-batch and was lowered to $30^{\circ} \mathrm{C}$ during induction. All process parameters were logged and controlled by the DASware ${ }^{\circledR}$ control.

Five hundred milliliters of sterile DeLisa pre-culture medium (DeLisa et al. 1999) supplemented with $0.1 \mathrm{~g} / \mathrm{L}$ ampicillin and $8 \mathrm{~g} / \mathrm{L}$ glucose were aseptically inoculated from frozen stocks $\left(1.5 \mathrm{~mL},-80^{\circ} \mathrm{C}\right)$. Pre-cultures were grown overnight $(20 \mathrm{~h})$ in $2500-\mathrm{mL}$ high-yield shake flasks in an Infors HR Multitronshaker (Infors, Bottmingen, Switzerland) at $37{ }^{\circ} \mathrm{C}$ and $250 \mathrm{rpm}$. One hundred-fifty milliliters of DeLisa batch medium (DeLisa et al. 1999) supplemented with $0.1 \mathrm{~g} / \mathrm{L}$ ampicillin and $10 \mathrm{~g} / \mathrm{L}$ glucose were inoculated with $15 \mathrm{~mL}$ of preculture. After sugar depletion, a fed-batch phase to reach about $25 \mathrm{~g}_{\text {cells }} / \mathrm{L}$ using a glucose feed with $250 \mathrm{~g} / \mathrm{L}$ glucose was 
carried out. Induction was performed by addition of $0.5 \mathrm{mM}$ IPTG or supplementing the feed with different amounts of lactose to reach the $q_{\mathrm{s}, \mathrm{glu}}$ and $q_{\mathrm{s} \text {, lac }}$ values displayed in Fig. $1 \mathrm{c}$.

\section{Sampling}

Samples were taken at the beginning and end of the batch and fed-batch phase, furthermore during the induction phase after $0,1,2,4,7,10$ and $12 \mathrm{~h}$. Quantification of biomass dry cell weight (DCW) was performed gravimetrically as in (Wurm et al. 2016); substrates and metabolites were measured by high-pressure liquid chromatography (HPLC) as in (Wurm et al. 2016).

\section{Product analysis}

Product titer quantification by reversed-phase HPLC Cell pellets of $5 \mathrm{~mL}$ fermentation broth were resuspended (100 mM Tris, $10 \mathrm{mM}$ EDTA pH 7.4) to $4.0 \mathrm{~g} / \mathrm{L} \mathrm{DCW}$ and homogenized at
1500 bar for six passages (EmulsiflexC3; Avestin, Ottawa, Canada). After centrifugation (15 min, $13,000 \mathrm{rcf}, 4{ }^{\circ} \mathrm{C}$ ), the supernatant was used for analysis of SP. For IB quantification, the pellet was washed twice [(i) $50 \mathrm{mM}$ Tris, $5 \mathrm{mM}$ EDTA, $\mathrm{pH}$ 8.0 ; (ii) $50 \mathrm{mM}$ Tris, $0.5 \mathrm{M} \mathrm{NaCl}, 0.02 \%(w / v)$ Tween $80, \mathrm{pH} 8$ ], aliquoted and stored at $-20^{\circ} \mathrm{C}$. Pellets were resuspended in a solution containing 1 part Tris-buffer ( $50 \mathrm{mM}$ Tris, $5 \mathrm{mM}$ EDTA, $\mathrm{pH} 8.0$ ) and four parts solubilization buffer (6 M guanidine hydrochloride $(\mathrm{GuHCl}), 50 \mathrm{mM}$ Tris, $\mathrm{pH} 8.0$ with $5.0 \%(v / v) 2$ mercaptoethanol added right before use), incubated for $2 \mathrm{~h}$ on a shaker at room temperature and vortexed every $30 \mathrm{~min}$. Product quantification was carried out by HPLC analysis (UltiMate 3000; Thermo Fisher, Waltham, MA, USA) using a reversed phase column (EC 150/4.6 Nucleosil 300-5 C8; Macherey-Nagel, Düren, Germany). The product was quantified with an UV detector (Thermo Fisher, Waltham, MA, USA) at $280 \mathrm{~nm}$ using bovine serum albumin as standard. Mobile phase was composed of water (buffer A) and acetonitrile (buffer B) both supplemented with $0.1 \%(v / v)$ tetrafluoride acetic acid. A linear gradient from

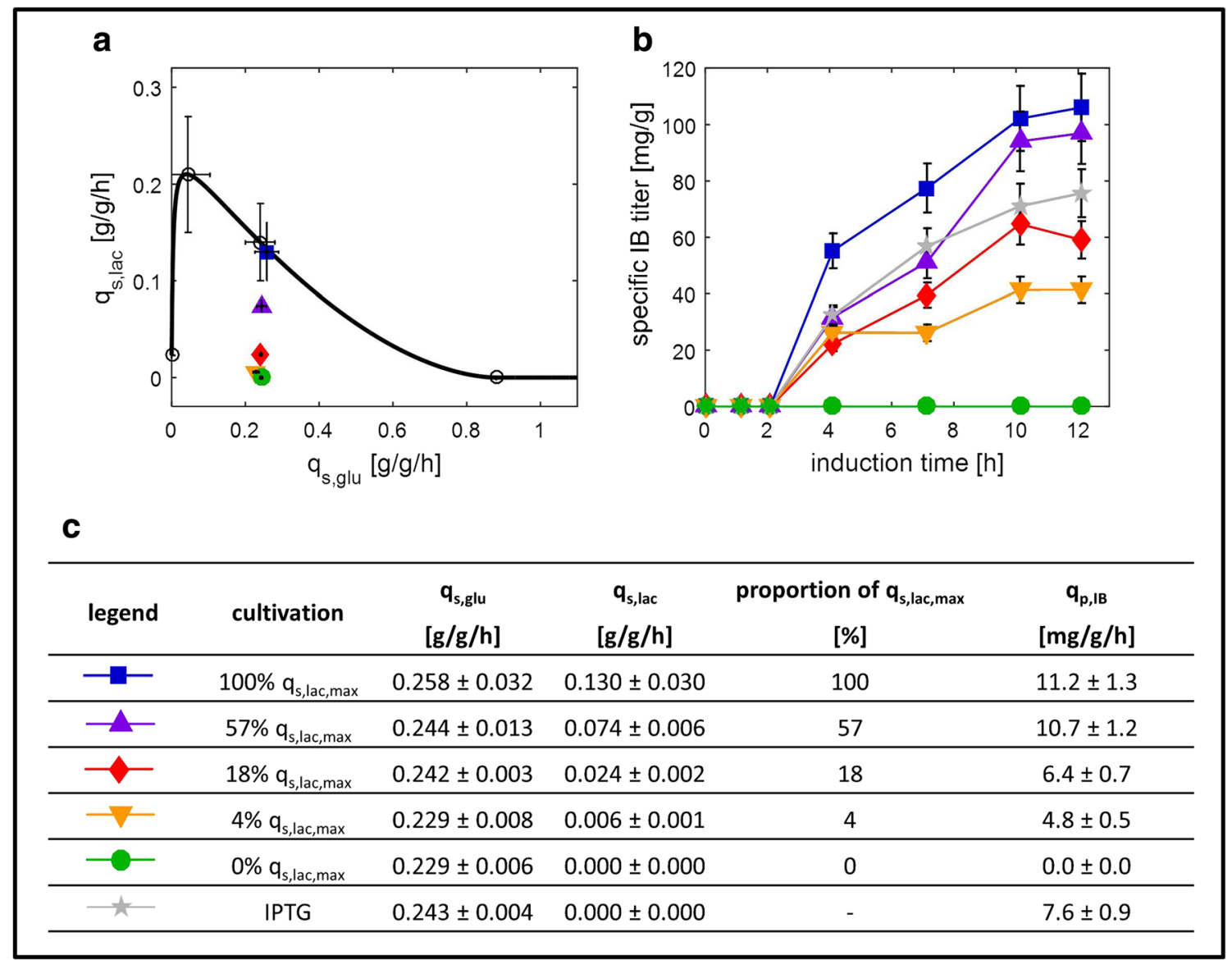

Fig. 1 Tuning IB formation rate. a Black line indicates the maximum specific uptake rate of lactose $\left(q_{\mathrm{s}, \text { lac }}\right)$ as a function of the specific uptake rate of glucose $\left(q_{\mathrm{s}, \mathrm{glu}}\right)$ for an Escherichia coli BL21(DE3) strain producing enhanced green fluorescent protein (eGFP). Data points (open circles) were obtained from several batch and fed-batch cultivations and fitted by the mechanistic model according to our previous study (Wurm et al. 2016, 2017). Colored symbols indicate performed experiments as shown in (b) and (c). Error bars indicate deviation of the respective $q_{\mathrm{s}}$ over induction time. b Specific IB titer in $\mathrm{mg} \mathrm{e}_{\mathrm{eGFP}} / \mathrm{g}_{\text {cells }}$ as a function of time for lactose and IPTG $(0.5 \mathrm{mM})$ induction. c Summary of specific sugar uptake rates $\left(q_{\mathrm{s}}\right)$ and specific IB formation rates $\left(q_{\mathrm{p}, \mathrm{IB}}\right)$. The error bars of the specific IB titers indicate the standard deviation (namely $11.25 \%$ ), which was identified by performing biological replicates of the center point (i.e., $18 \% q_{\mathrm{s}, \mathrm{lac}, \max }$ ) 
$30 \%(v / v)$ acetonitrile to $100 \%$ acetonitrile was applied. The error bars in all figures displaying product titers were identified by performing biological replicates of the center point $(18 \% q$ s,lac,max) and was quantified to be $11.25 \%$ for IBs and $11.50 \%$ for SP.

\section{Size determination by scanning electron microscopy (SEM)} Washed and aliquoted IB samples were resuspended in ultrapure water. One hundred microliters of appropriate dilution of the suspension were pipetted on a gold-sputtered $(10-50 \mathrm{~nm})$ polycarbonate filter (Millipore-Merck, Darmstadt, Germany) using reusable syringe filter holders with a diameter of $13 \mathrm{~mm}$ (Sartorius, Goettingen, Germany). One hundred microliters of ultrapure water were added and pressurized air was used for subsequent filtration. Additional $200 \mu \mathrm{L}$ of ultrapure water were used for washing. The wet filters were fixed on a SEM sample holder using graphite adhesive tape and subsequently sputtered with gold to increase the contrast of the sample. SEM was performed using a QUANTA FEI SEM (Thermo Fisher, Waltham, MA, USA) using a secondary electron detector (SED). The acceleration voltage of the electron beam was set between 3 to $5 \mathrm{kV}$. The diameters of the IBs were evaluated by measuring 50 IBs on SEM pictures using the Image J plugin Fiji (Laboratory for Optical and Computational Instrumentation (LOCI), University of Wisconsin-Madison, USA).

Morphology analysis by atomic force microscopy (AFM) For determination of morphological aspects of IBs, samples were prepared the same way as for SEM except for gold sputtering, which was not necessary for these measurements. Measurements were performed on a WITec alpha 300RSA+ (WITec GmbH, Ulm, Germany) in tapping mode (AC).

Secondary structure analysis by infrared spectroscopy (IR) IR measurements were performed by an external-cavity quantum cascade laser-based IR transmission setup using the path length of $38 \mu \mathrm{m}$, described in detail by Alcaraz et al. (Alcaraz et al. 2015). Calculation of degree of spectral overlap by $s_{1,2}$ has been described by Schwaighofer et al. (Schwaighofer et al. 2016).

\section{Solubilization and refolding of IB}

Homogenized cell pellets were resuspended in ultrapure water and $30 \mu \mathrm{L}$ of the suspension were pipetted into 96 microtiter plates. Subsequently, $70 \mu \mathrm{L}$ of urea stock solution supplemented with $50 \mathrm{mM}$ Tris at $\mathrm{pH} 8$ were simultaneously added to each well (Qi et al. 2015).

Refolding was carried out at $30{ }^{\circ} \mathrm{C}$ for $4.5 \mathrm{~h}$ by diluting $10 \mu \mathrm{L}$ of solubilizate with $190 \mu \mathrm{L}$ of refolding buffer $(50 \mathrm{mM}$ Tris, $100 \mathrm{mM} \mathrm{NaCl}, 1 \mathrm{mM}$ DTT, pH 7.5) (Enoki et al. 2004) resulting in a final protein concentration of $0.2 \mathrm{mg} / \mathrm{mL}$.

\section{Impurity monitoring}

Impurity monitoring to asses purity after solubilization and refolding was carried out chromatographically (UltiMate 3000; Thermo Fisher, Waltham, MA, USA) using a highperformance size-exclusion chromatography column (MAbPac ${ }^{\mathrm{TM}}$ SEC-1, Thermo Scientific, Waltham, MA, USA). For solubilized samples a $\mathrm{GuHCl}$ buffer ( $4 \mathrm{M}$ $\mathrm{GuHCl}, 50 \mathrm{mM}$ Bis-Tris, $300 \mathrm{mM} \mathrm{NaCl}, \mathrm{pH} 6.8$ ) and for refolded samples a phosphate buffer $\left(100 \mathrm{mM} \mathrm{Na}_{2} \mathrm{HPO}_{4}\right.$, $300 \mathrm{mM} \mathrm{NaCl}, \mathrm{pH}$ 6.8) were used as mobile phase. The flowrate was kept constant at $0.2 \mathrm{~mL} / \mathrm{min}$, the column oven temperature was $25^{\circ} \mathrm{C}$, and the method lasted $17 \mathrm{~min}$. An exemplary chromatogram is displayed in Supplementary Fig. S2.

\section{Results}

\section{Product titer}

To potentially tune the titer of eGFP, we adjusted four different $q_{\mathrm{s}, \text { lac }}$ at a $q_{\mathrm{s}, \mathrm{glu}}$ of around $0.25 \mathrm{~g} / \mathrm{g} / \mathrm{h}$ (Fig. 1a, c), which allows both cell growth and increased recombinant product formation (Wurm et al. 2016). Additionally, we performed a control experiment without induction to rule out effects of basal expression, as the pET system is described to be leaky (Huang et al. 2012; Jia and Jeon 2016), as well as an experiment where we induced with the standard inducer IPTG at a concentration of 0.5 mM (Bashir et al. 2016; Durani et al. 2012; Jia and Jeon 2016; Marbach and Bettenbrock 2012; Rosano and Ceccarelli 2014; Wurm et al. 2016). To assure reproducibility, we performed a biological replicate of the center point (i.e., $18 \%$ $\left.q_{\mathrm{s}, \text { lac,max }}\right)$. The biomass concentration during induction of all cultivations can be found in the Supplementary Fig. S3.

\section{IB titer}

Figure $1 \mathrm{~b}$ presents the specific IB titer, measured by reversed phase chromatography, as a function of time for $12 \mathrm{~h}$ of induction. Throughout the entire induction, there was a clear correlation between the specific IB formation rate $\left(q_{\mathrm{p}, \text { IB }}\right)$ and $q_{\mathrm{s}, \text { lac }}$, namely, the higher $q_{\mathrm{s} \text {, lac }}$ and the higher $q_{\mathrm{p}, \mathrm{IB}}$, leading to final titers which varied by a factor of nearly three after $12 \mathrm{~h}$ of induction (40 vs. $110 \mathrm{mg}_{\mathrm{eGFPIB}} / \mathrm{g}_{\text {cells }}$; Fig. 1b). Interestingly, we obtained a higher specific IB titer when we adjusted $q_{\mathrm{s} \text {, lac }}$ at $100 \% q_{\mathrm{s}, \text { lac, } \max }$ and $57 \% q_{\mathrm{s}, \text { lac,max }}$, respectively, compared to induction with $0.5 \mathrm{mM}$ IPTG (Fig. 1b, c), emphasizing the power of lactose as a nontoxic and cheap inducer. Surprisingly, we found IBs only after more than $2 \mathrm{~h}$ of induction (Fig. 1b). Since we detected soluble eGFP right after induction (Supplementary Table S1), we speculate that the 
a

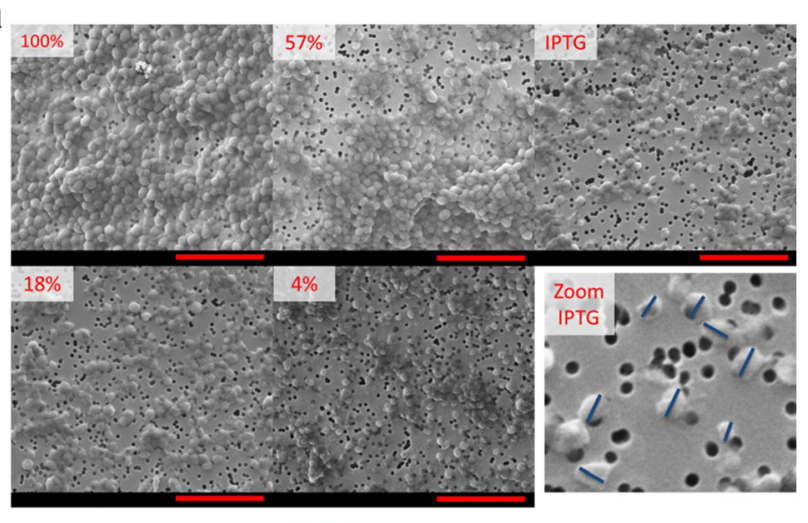

b

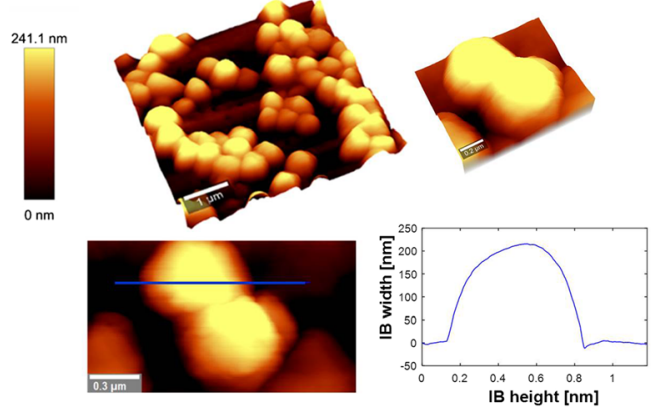

Fig. 2 Tuning the size of IBs. a Scanning electron microscopy pictures of IBs from different cultivations used to asses IB size, as exemplarily shown in lower right figure. Percentage indicates proportion of maximum specific lactose uptake rate $\left(q_{\mathrm{s}, \text { lac }}\right)$ used for induction. Red scale bars: $5 \mu \mathrm{m}$. 3.5-fold zoom for IPTG induction (lower right). b (i) exemplary atomic force microscopy picture of typical IBs showing spherical shape, (ii) and (iii) zoom in on IB particle, and (iv) topography cross-

amount and the size of IBs in the first $2 \mathrm{~h}$ of induction were below the detection limit of the applied analytics.

\section{Soluble and total product titer}

Even though the main focus of this study was the investigation of IBs, we also analyzed SP and total product titers. With respect to SP, we observed the same correlation between $q_{\mathrm{s} \text {,lac }}$ and $q_{\mathrm{p}}$ as seen for IBs during the first $4 \mathrm{~h}$ of induction, namely, the higher $q_{\mathrm{s} \text {, lac }}$ and the higher $q_{\mathrm{p}, \mathrm{SP}}$. However, after $12 \mathrm{~h}$ of induction, the highest specific SP titer was obtained at the lowest $q$ s,lac. Apparently, cells which were strongly induced right from the beginning of induction somehow reduced $q_{\mathrm{p}, \mathrm{SP}}$ after a certain time, whereas cells induced at a low $q_{\mathrm{s} \text {,lac }}$ of only $4 \% q_{\mathrm{s} \text {,lac,max }}$ steadily produced SP over time (Supplementary Table S1).

The total productivity also showed a clear trend in the first $4 \mathrm{~h}$ of induction, as increasing $q_{\mathrm{s} \text {, lac }}$ gave more total product (Supplementary Table S1). However, after $12 \mathrm{~h}$ of induction, all induction conditions resulted in comparable amounts of total product.
C

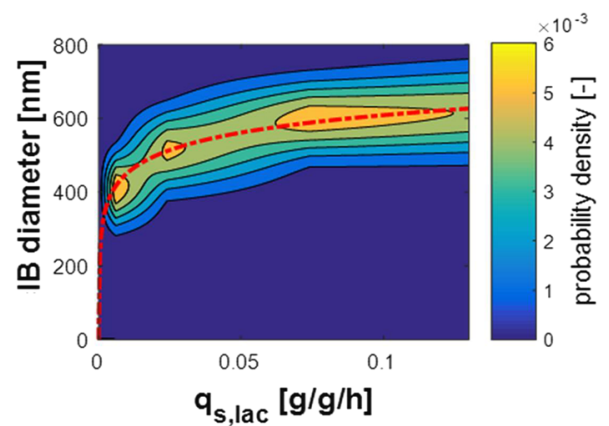

\begin{tabular}{cc}
\hline $\begin{array}{c}\text { cultivation } \\
\text { name }\end{array}$ & $\begin{array}{c}\text { IB-diameter } \\
\text { [nm] }\end{array}$ \\
\hline $100 \% \mathrm{q}_{\mathrm{s}, \mathrm{lac}, \max }$ & $616.9 \pm 79.9$ \\
\hline $57 \% \mathrm{q}_{\mathrm{s}, \mathrm{lac} \text { max }}$ & $600.0 \pm 70.1$ \\
\hline $18 \% \mathrm{q}_{\mathrm{s}, \mathrm{lac} \text { max }}$ & $513.2 \pm 74.3$ \\
\hline $4 \% \mathrm{q}_{\mathrm{s}, \text { lac, } \max }$ & $408.0 \pm 66.3$ \\
\hline $0 \% \mathrm{q}_{\mathrm{s}, \text { lac, } \max }$ & - \\
\hline $\mathrm{IPTG}^{\mathrm{P} T}$ & $489.9 \pm 73.0$ \\
\hline
\end{tabular}

section of an isolated IB (indicated as a blue line in iii). c Probability density plot of IB size distribution after $12 \mathrm{~h}$ of induction as a function of $q_{\mathrm{s}, \text { lac }}$ showing that IB size can be tuned by $q_{\mathrm{s} \text {,lac. }}$. Red-dashed line indicates logarithmic fit between IB size and $q_{\mathrm{s}, \text { lac }}$ (degree of freedom $=2, R^{2}=$ 0.99 ). IB diameter with standard deviation from different cultivations after $12 \mathrm{~h}$ of induction are shown in the table. Standard deviation was evaluated from measuring 50 IBs per sample
Summarizing, with respect to product titer, we concluded that, (1) $q_{\mathrm{p}, \mathrm{IB}}$ can be tuned by $q_{\mathrm{s} \text {,lac }}$ over the whole induction time; (2) in the first $4 \mathrm{~h}$ of induction, higher $q_{\mathrm{s}, \text { lac }}$ gave higher $q_{\mathrm{p}, \mathrm{SP}}$, while after $12 \mathrm{~h}$ of induction, this situation was reversed; and (3) after $12 \mathrm{~h}$ of induction, the amount of total product was comparable for all induction conditions tested.

\section{Tuning IB properties}

In order to potentially link IB properties to induction conditions, we analyzed size, morphology, size distribution, and the presence of secondary structures of the formed IBs.

\section{IB size}

We assessed IB size by scanning electron microscopy (SEM; Fig. 2a), supported the results by atomic force microscopy (AFM; Fig. 2b) and correlated the IB size to the respective $\mathrm{q}_{\mathrm{s}, \mathrm{lac}}$ (Fig. 2c). In fact, we were able to tune IB size by induction, as shown in Fig. 2c. A clear 
Fig. 3 Size distribution of IBs over induction time. a Probability density plot of IB size distribution as a function of induction time indicating that IB size increases, while also, the distribution gets broader over time for different induction conditions. b IB diameter with standard deviation from different cultivations conditions at different time points of induction

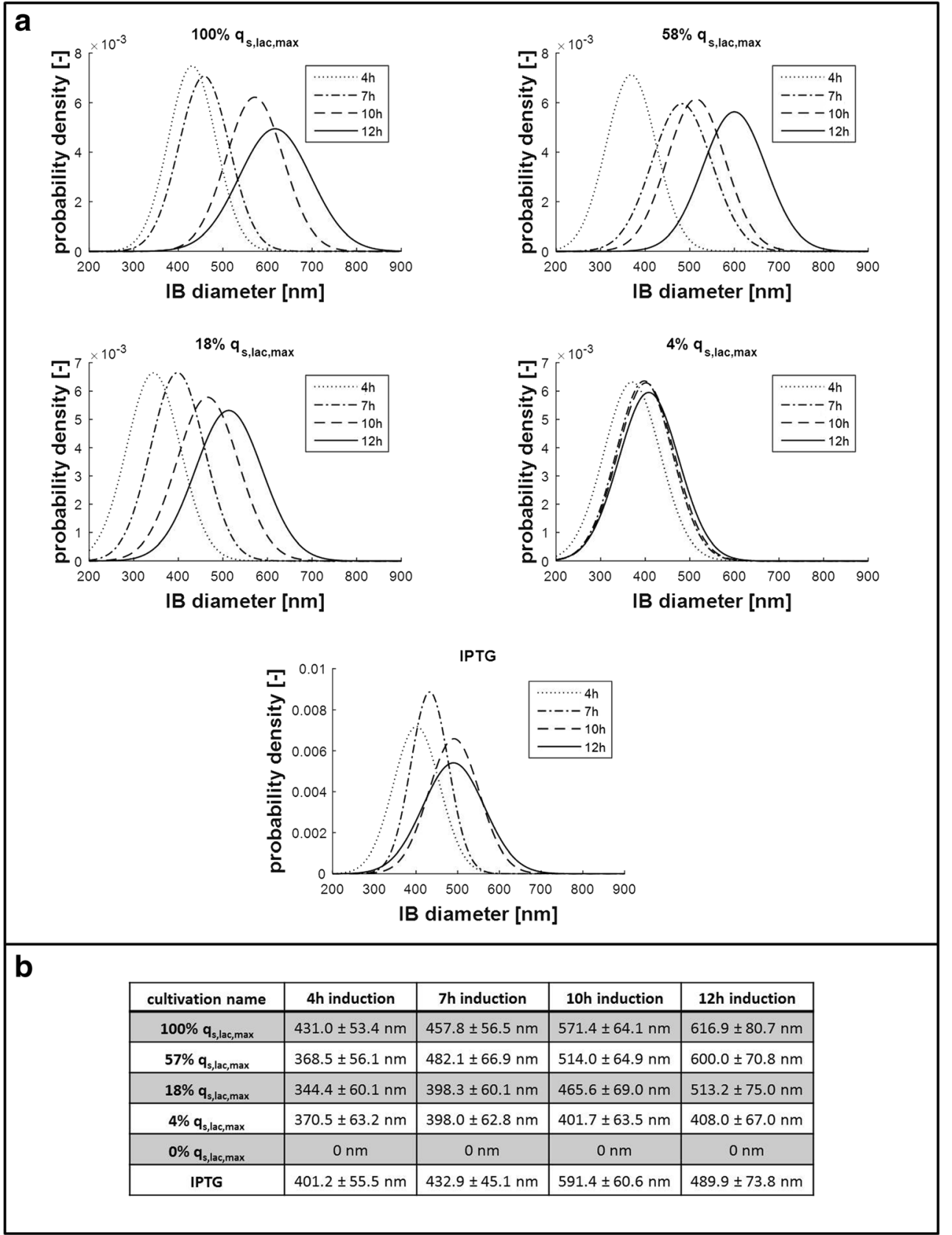

correlation between $q_{\text {s,lac }}$ and IB size was observed: smaller IBs were produced when less lactose was specifically taken up (logarithmic fit, degree of freedom = 2, $\left.R^{2}=0.991\right)$.

\section{IB morphology}

Using AFM analysis, we found that eGFP IBs were of spherical shape (exemplarily shown in Fig. 2b), whose surface area can be calculated by $A=d^{2} \cdot \pi$. This underlines the high importance of the IB diameter $(d)$ as it impacts the surface area $(A)$, by the power of 2 . Thus, it is advantageous to produce large IBs in order to minimize the surface area, where impurities can potentially adhere to.

\section{IB size distribution as a function of time}

We found that not only IB size, but also IB size distribution increased as a function of induction time (Fig. 3). Although this trend was not as apparent for induction by IPTG, we observed an increasingly broad size distribution of formed IBs for all experiments with lactose induction (100\% $q_{\mathrm{s}, \text { lac }}$, $57 \% q_{\mathrm{s}, \text { lac }}, 18 \% q_{\mathrm{s}, \text { lac }}$, and $\left.4 \% q_{\mathrm{s}, \mathrm{lac}}\right)$. We explain this 


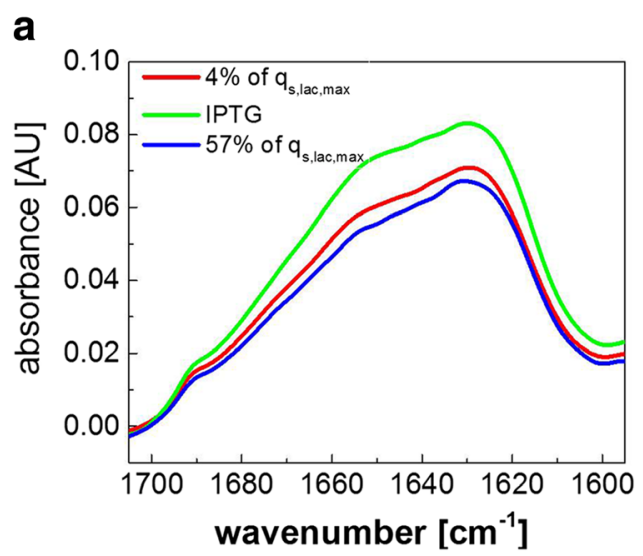

Fig. 4 Secondary structure of IBs measured by infrared (IR) spectroscopy. a IR spectra of IBs from different induction regimes. Maxima for $\beta$ sheet secondary structure appear at approx. 1630 and $1690 \mathrm{~cm}^{-1}$ in the IR spectrum, whereas the shoulder at approx. $1655 \mathrm{~cm}^{-1}$ is attributed to $\alpha$ helical secondary structure. $\mathbf{b}$ Table shows degree of spectral overlap $\left(s_{1,2}\right)$ for IBs from different induction regimes $\left(4 \% q_{\mathrm{s} \text {,lac,max }}\right.$ (small IBs,

phenomenon by the generally accepted hypothesis that the IB is passed on to only one daughter cell after cell division, leaving one daughter cell without IB and one daughter cell with an IB that continues to grow (Peternel and Komel 2011). Thus, in order to get an IB population of distinct size, which is not only important for IB processing, but also for potential direct application as nanomaterials and biomaterials (Diez-Gil et al. 2010; Garcia-Fruitos et al. 2009; Garcia-Fruitos et al. 2012; Peternel and Komel 2011; Upadhyay et al. 2012; Villaverde et al. 2015), we recommend short induction times.

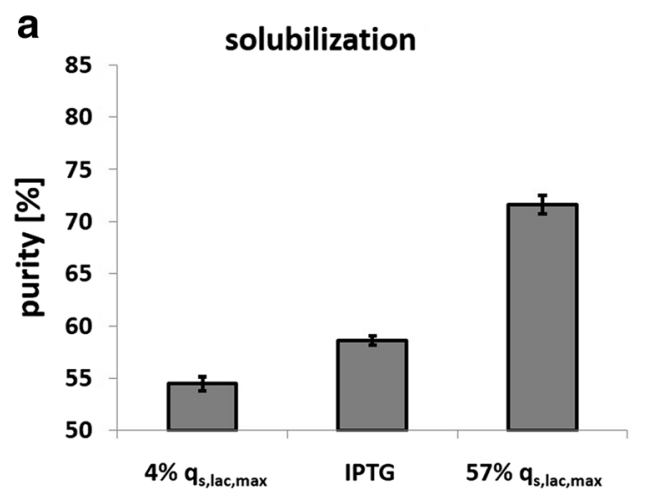

C

\begin{tabular}{cccc}
\hline sample & size IB [nm] & purity solubilization [\%] & purity refolding [\%] \\
\hline $4 \% \mathrm{q}_{\mathrm{s}, \mathrm{lac}, \max }$ & $408.0 \pm 66.3$ & $54.5 \pm 0.7$ & $74.7 \pm 1.2$ \\
\hline IPTG & $489.9 \pm 73.0$ & $58.6 \pm 0.5$ & $81.2 \pm 0.1$ \\
\hline $57 \% \mathrm{q}_{\mathrm{s}, \text { lac, } \max }$ & $600.0 \pm 70.1$ & $71.6 \pm 0.9$ & $82.7 \pm 2.2$ \\
\hline
\end{tabular}

Fig. 5 Impact of IB size on IB purity. a Purity determined by HPLC impurity monitoring using size exclusion chromatography (SEC) after solubilization with $2 \mathrm{M}$ urea of IBs with a small $(\varnothing=408 \mathrm{~nm})$, medium $(\varnothing=490 \mathrm{~nm})$ and large $(\varnothing=600 \mathrm{~nm})$ diameter. Standard deviation was

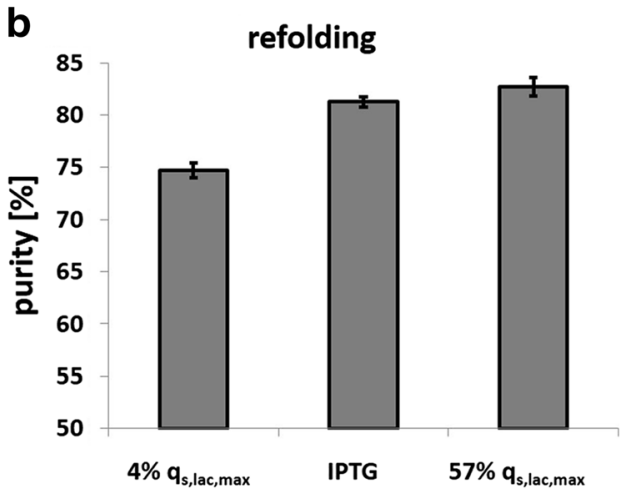

b

\begin{tabular}{|c|c|c|c|}
\hline$S_{1,2}$ & LAC_4\% & IPTG & LAC_57\% \\
\cline { 1 - 1 } LAC_4\% & & 0.9999 & 0.9998 \\
\hline IPTG & & 0.9996 \\
\hline \multirow{2}{*}{ LAC_57\% } & & \\
\hline
\end{tabular}

$\varnothing=408 \mathrm{~nm}$ ); IPTG (medium IBs, $\varnothing=490 \mathrm{~nm}$ ); and $57 \% q_{\mathrm{s} \text {,lac,max }}$ (large IBs, $\varnothing=600 \mathrm{~nm}$ )) calculated according to Schwaighofer et al. (Schwaighofer et al. 2016) demonstrating a very high degree of spectral overlap for all samples. The value of $s_{1,2}$ ranges from 0 to 1 , corresponding to no overlapping and complete overlapping, respectively

\section{IB secondary structures}

The secondary structures found in the agglomerated product can affect its properties and also the processing of IBs. Therefore, we assessed the secondary structure of the IBs by infrared (IR) spectroscopy. IR spectroscopy showed high similarity and overlaps in the IR spectra of all IBs indicating that the amount of correctly folded secondary structures were not significantly different (evaluated by degree of spectral overlap $>99.9 \%$, (Schwaighofer et al. 2016)) independent of the

evaluated from technical duplicates. b Purity of eGFP determined by HPLC impurity monitoring using SEC after refolding. Standard deviation was evaluated from technical duplicates. c Overview of results from solubilization and refolding with standard deviations 
induction strategy (exemplarily shown in Fig. 4 for $4 \% q$ s,lac,max (small IBs, $\varnothing=408 \mathrm{~nm}$ ); IPTG (medium IBs, $\varnothing=$ $490 \mathrm{~nm}$ ); and $57 \% q_{\mathrm{s}, \text { lac,max }}$ (large IBs, $\varnothing=600 \mathrm{~nm}$ ).

\section{IB processing}

We hypothesized that the IB diameter and thus the surface area are crucial for subsequent IB processing, as (1) more impurities can adhere on particles with a larger surface area and (2) solubilization efficiency depends on accessibility to protein aggregates. To test the impact of the specific surface area $\left(\mathrm{nm}^{2} / \mathrm{g}_{\mathrm{IB}}\right)$ on IB processing and potentially omit necessary IB washing steps during production processes, we solubilized the different IBs with 2 , 4, and $6 \mathrm{M}$ urea, respectively, without any prior washing step. We found solubilization yields of $>99 \%$ for all IB preparations and all three urea concentrations. Since solubilizing at lower urea concentrations has the advantage of conserving correctly folded secondary structures resulting in an increased refolding yield (Margreiter et al. 2008; Singh et al. 2015b; Upadhyay et al. 2012), we used $2 \mathrm{M}$ urea for solubilization of IBs to analyze IB purity. We used IBs from induction with IPTG and $4 \% q_{\mathrm{s}, \text { lac, max }}$ and $57 \% q_{\mathrm{s}, \text { lac, max }}$, respectively, to cover IBs of different sizes (Fig. 5). As shown in Fig. 5a, the purity of the IBs differed vastly. The high specific surface area of the small IBs formed at $4 \%$ $q_{\mathrm{s}, \text { lac,max }}$ caused the adherence of more impurities compared to the low specific surface area of large IBs formed at $57 \% q_{\mathrm{s}, \text { lac,max }}$ (Fig. 5a, c). While small IBs showed a purity of only $55 \%$, large IBs had a purity of more than $70 \%$. Fig. $5 \mathrm{~b}$ shows the purity after refolding, which was done by a standard dilution approach tailored for eGFP (Enoki et al. 2004). The purity of all IB preparations increased after refolding, as host cell derived impurities precipitated during this process step. After refolding, the purity was increased to $75 \%$ for small IBs, $81 \%$ for medium IBs, and $83 \%$ for large IBs. This observation confirms our hypothesis that a higher specific surface area attracts more impurities. The purity of IBs is of great importance as the presence of impurities can potentially reduce the refolding yield (Singh et al. 2015a). Furthermore, IB purity is a key aspect once IBs are directly used as nanomaterials and biomaterials (Diez-Gil et al. 2010; Garcia-Fruitos et al. 2009, 2012; Peternel and Komel 2011; Upadhyay et al. 2012; Villaverde et al. 2015).

Summarizing, we were able to show that tailored induction by lactose not only allows tuning of IBs size, but also IB purity. For the three different IB preparations we obtained a comparable refolding yield of $>95 \%$. We expected these comparable values since we had found the same amount of correctly folded secondary structures in the different IBs by IR spectroscopy before (Fig. 4).

\section{Discussion}

In this study, we showed that a mixed feed strategy with glucose and lactose not only impacts total product, soluble product, and IB titer in E. coli, but also IB properties, which in turn affects IB processing. Our method of tailored lactose induction allows precise tuning of the specific IB formation rate and is, thus, a valuable alternative to expression tuning by reducing the overall cell metabolism. Moreover, our approach allows prolonged production times and thus higher overall titers. Furthermore, it is of great interest that the size and the size distribution of IBs can be tuned by our method.

Size is an important property of IBs, since it significantly impacts IB harvesting and processing (Upadhyay et al. 2012). Furthermore, IB size is a crucial factor for potential direct applications of IBs as nanomaterials and biomaterials in regenerative medicine (Diez-Gil et al. 2010; Garcia-Fruitos et al. 2009, 2012; Peternel and Komel 2011; Upadhyay et al. 2012; Villaverde et al. 2015). We also showed that IB size correlates with purity and thus affects IB processing. We suggest to induce the cells at $q_{\mathrm{s} \text {,lac,max }}$ to obtain highest productivity and generate large IBs, which leads to a lower specific surface area and thus less adherent impurities. For eGFP IBs, we did not find any impact of induction on the amount of correctly folded secondary structures in the IBs. However, for more complex proteins, which often easily overwhelm the folding machinery, as well as for periplasmic proteins, where translocation is the rate limiting step, our strategy of tuning transcription by $q_{\mathrm{s}, \text { lac }}$ might be required to obtain higher product titers. Also, when expressing a protein which is toxic to $E$. coli and negatively affects its metabolism, it is beneficial to regulate recombinant protein expression to reduce metabolic burden and potential cell death. Summarizing, we present a method, which allows (1) tuning the specific formation rate of IBs, as well as (2) adjusting size, size distribution, and purity of IBs, which is not only fundamental for IB processing, but also for applications where IBs are directly used.

Acknowledgements Open access funding provided by TU Wien (TUW). The authors acknowledge Julian Kager for his technical support during the bioreactor cultivations and Paul Kroll for his support in data presentation. Furthermore, we thank the Analytical Instrumentation Center of the TU Wien for the access to the infrastructure.

Author contribution DJW, JQ and JM performed and evaluated the experiments. BE assisted in planning and carrying out downstream processing. DJW and CS performed and evaluated SE measurements. AS performed and evaluated IR measurements, KW performed and evaluated AFM measurements, and BL supervised these analyses. VR assisted in performing and evaluating chromatography for product analysis. OS planned, initiated and supervised the study. DJW, JQ, BE and OS 
designed the study. $\mathrm{CH}$ gave valuable scientific input. DJW and OS wrote the manuscript.

Funding information Financial support was provided by the Austrian Research Funding Association (FFG) under the scope of the COMET Program within the research project "Industrial Methods for Process Analytical Chemistry-from Measurement Technologies to Information Systems (imPACts)" (contract \#843546). This study also received financial support from the TU Wien University Library through its Open Access Funding Program.

\section{Compliance with ethical standards}

Ethical approval This article does not contain any studies with human participants or animals performed by any of the authors.

Conflict of interest The authors declare that they have no conflict of interest.

Open Access This article is distributed under the terms of the Creative Commons Attribution 4.0 International License (http:// creativecommons.org/licenses/by/4.0/), which permits unrestricted use, distribution, and reproduction in any medium, provided you give appropriate credit to the original author(s) and the source, provide a link to the Creative Commons license, and indicate if changes were made.

\section{References}

Alcaraz MR, Schwaighofer A, Kristament C, Ramer G, Brandstetter M, Goicoechea H, Lendl B (2015) External-cavity quantum cascade laser spectroscopy for mid-IR transmission measurements of proteins in aqueous solution. Anal Chem 87(13):6980-6987. https:// doi.org/10.1021/acs.analchem.5b01738

Baneyx F (1999) Recombinant protein expression in Escherichia coli. Curr Opin Biotechnol 10:411-421. https://doi.org/10.1016/S09581669(99)00003-8

Bashir H, Ahmed N, Khan MA, Zafar AU, Tahir S, Khan MI, Khan F, Husnain T (2016) Simple procedure applying lactose induction and one-step purification for high-yield production of rhCIFN. Biotechnol Appl Biochem 63(5):708-714. https://doi.org/10.1002/ bab.1426

Bruckner R, Titgemeyer F (2002) Carbon catabolite repression in bacteria: choice of the carbon source and autoregulatory limitation of sugar utilization. FEMS Microbiol Lett 209(2):141-148. https:// doi.org/10.1111/j.1574-6968.2002.tb11123.x

Choi JH, Keum KC, Lee SY (2006) Production of recombinant proteins by high cell density culture of Escherichia coli. Chem Eng Sci 61(3):876-885. https://doi.org/10.1016/j.ces.2005.03.031

DeLisa MP, Li JC, Rao G, Weigand WA, Bentley WE (1999) Monitoring GFP-operon fusion protein expression during high cell density cultivation of Escherichia coli using an on-line optical sensor. Biotechnol Bioeng 65(1):54-64. https://doi.org/10.1002/(Sici) 1097-0290(19991005)65:1<54::Aid-Bit7>3.0.Co;2-R

Diez-Gil C, Krabbenborg S, Garcia-Fruitos E, Vazquez E, RodriguezCarmona E, Ratera I, Ventosa N, Seras-Franzoso J, Cano-Garrido O, Ferrer-Miralles N, Villaverde A, Veciana J (2010) The nanoscale properties of bacterial inclusion bodies and their effect on mammalian cell proliferation. Biomaterials 31(22):5805-5812. https://doi. org/10.1016/j.biomaterials.2010.04.008

Durani V, Sullivan BJ, Magliery TJ (2012) Simplifying protein expression with ligation-free, traceless and tag-switching plasmids. Protein Expr Purif 85:9-17. https://doi.org/10.1016/j.pep.2012.06.007
Dvorak P, Chrast L, Nikel PI, Fedr R, Soucek K, Sedlackova M, Chaloupkova R, de Lorenzo V, Prokop Z, Damborsky J (2015) Exacerbation of substrate toxicity by IPTG in Escherichia coli BL21(DE3) carrying a synthetic metabolic pathway. Microb Cell Fact 14:201. https://doi.org/10.1186/s12934-015-0393-3

Eiberle MK, Jungbauer A (2010) Technical refolding of proteins: do we have freedom to operate? Biotechnol J 5(6):547-559. https://doi. org/10.1002/biot.201000001

Enoki S, Saeki K, Maki K, Kuwajima K (2004) Acid denaturation and refolding of green fluorescent protein. Biochemistry 43(44):14238 14248. https://doi.org/10.1021/bi048733+

Fruchtl M, Sakon J, Beitle R (2015) Expression of a collagen-binding domain fusion protein: effect of amino acid supplementation, inducer type, and culture conditions. Biotechnol Prog 31:503-509. https:// doi.org/10.1002/btpr.2048

Garcia-Fruitos E, Rodriguez-Carmona E, Diez-Gil C, Ferraz RM, Vazquez E, Corchero JL, Cano-Sarabia M, Ratera I, Ventosa N, Veciana J, Villaverde A (2009) Surface cell growth engineering assisted by a novel bacterial. Nanomaterial Adv Mater 21(42): 4249-4253. https://doi.org/10.1002/adma.200900283

Garcia-Fruitos E, Vazquez E, Diez-Gil C, Corchero JL, Seras-Franzoso J, Ratera I, Veciana J, Villaverde A (2012) Bacterial inclusion bodies: making gold from waste. Trends Biotechnol 30(2):65-70. https:// doi.org/10.1016/j.tibtech.2011.09.003

Gatti-Lafranconi P, Natalello A, Ami D, Doglia SM, Lotti M (2011) Concepts and tools to exploit the potential of bacterial inclusion bodies in protein science and biotechnology. FEBS J 278(14): 2408-2418. https://doi.org/10.1111/j.1742-4658.2011.08163.x

Haddadin FT, Harcum SW (2005) Transcriptome profiles for high-celldensity recombinant and wild-type Escherichia coli. Biotechnol Bioeng 90(2):127-153. https://doi.org/10.1002/bit.20340

Huang CJ, Lin H, Yang X (2012) Industrial production of recombinant therapeutics in Escherichia coli and its recent advancements. J Ind Microbiol Biotechnol 39(3):383-399. https://doi.org/10.1007/ s10295-011-1082-9

Jevsevar S, Gaberc-Porekar V, Fonda I, Podobnik B, Grdadolnik J, Menart V (2005) Production of nonclassical inclusion bodies from which correctly folded protein can be extracted. Biotechnol Prog 21(2):632-639. https://doi.org/10.1021/bp[0497839

Jia B, Jeon CO (2016) High-throughput recombinant protein expression in Escherichia coli: current status and future perspectives. Open Biol 6(8):160196. https://doi.org/10.1098/rsob.160196

Johnson JL, Brooker RJ (2004) Control of H+/lactose coupling by ionic interactions in the lactose permease of Escherichia coli. J Membr Biol 198:135-146. https://doi.org/10.1007/s00232-004-0667-X

Joseph BC, Pichaimuthu S, Srimeenakshi S, Murthy M, Selvakumar K, Ganesan M, Manjunath SR (2015) An overview of the parameters for recombinant protein expression in Escherichia coli. J Cell Sci 6(05):1. https://doi.org/10.4172/2157-7013.1000221

Kaback HR (2015) A chemiosmotic mechanism of symport. Proc Natl Acad Sci USA 112:1259-1264. https://doi.org/10.1073/pnas. 1419325112

Kremling A, Geiselmann J, Ropers D, de Jong H (2015) Understanding carbon catabolite repression in Escherichia coli using quantitative models. Trends Microbiol 23:99-109. https://doi.org/10.1016/j.tim. 2014.11.002

Liu M, Feng X, Ding Y, Zhao G, Liu H, Xian M (2015) Metabolic engineering of Escherichia coli to improve recombinant protein production. Appl Microbiol Biotechnol 99(24):10367-10377. https://doi.org/10.1007/s00253-015-6955-9

Ma X, Su E, Zhu Y, Deng S, Wei D (2013) High-level expression of glutaryl-7-aminocephalosporanic acid acylase from Pseudomonas diminuta NK703 in Escherichia coli by combined optimization strategies. J Biotechnol 168:607-615. https://doi.org/10.1016/j. jbiotec.2013.08.024 
Marbach A, Bettenbrock K (2012) Lac operon induction in Escherichia coli: systematic comparison of IPTG and TMG induction and influence of the transacetylase LacA. J Biotechnol 157:82-88. https:// doi.org/10.1016/j.jbiotec.2011.10.009

Margreiter G, Schwanninger M, Bayer K, Obinger C (2008) Impact of different cultivation and induction regimes on the structure of cytosolic inclusion bodies of TEM1- $\beta$-lactamase. Biotechnol J 3(9-10): 1245-1255. https://doi.org/10.1002/biot.200800072

Marschall L, Sagmeister P, Herwig C (2016) Tunable recombinant protein expression in E. coli: enabler for continuous processing? Appl Microbiol Biotechnol 100(13):5719-5728. https://doi.org/10.1007/ s00253-016-7550-4

Marston FA (1986) The purification of eukaryotic polypeptides synthesized in Escherichia coli. Biochem J 240(1):1-12. https://doi.org/10. 1042/bj2400001

Peternel S, Komel R (2011) Active protein aggregates produced in Escherichia coli. Int J Mol Sci 12(12):8275-8287. https://doi.org/ 10.3390/ijms 12118275

Peternel S, Grdadolnik J, Gaberc-Porekar V, Komel R (2008a) Engineering inclusion bodies for non denaturing extraction of functional proteins. Microb Cell Factories 7(1):34. https://doi.org/10. 1186/1475-2859-7-34

Peternel S, Jevsevar S, Bele M, Gaberc-Porekar V, Menart V (2008b) New properties of inclusion bodies with implications for biotechnology. Biotechnol Appl Biochem 49(4):239-246. https://doi.org/ 10.1042/BA20070140

Qi XM, Sun YF, Xiong SD (2015) A single freeze-thawing cycle for highly efficient solubilization of inclusion body proteins and its refolding into bioactive form. Microb Cell Factories 14(1):24. https://doi.org/10.1186/s12934-015-0208-6

Ramon A, Senorale-Pose M, Marin M (2014) Inclusion bodies: not that bad. Front Microbiol 5:56. https://doi.org/10.3389/fmicb.2014. 00056

Rosano GL, Ceccarelli EA (2014) Recombinant protein expression in Escherichia coli: advances and challenges. Front Microbiol 5:172. https://doi.org/10.3389/fmicb.2014.00172

Schmidt FR (2004) Recombinant expression systems in the pharmaceutical industry. Appl Microbiol Biotechnol 65(4):363-372. https:// doi.org/10.1007/s00253-004-1656-9

Schwaighofer A, Alcaraz MR, Araman C, Goicoechea H, Lendl B (2016) External cavity-quantum cascade laser infrared spectroscopy for secondary structure analysis of proteins at low concentrations. Sci Rep 6(1):33556. https://doi.org/10.1038/srep33556

Sina M, Farajzadeh D, Dastmalchi S (2015) Effects of environmental factors on soluble expression of a humanized anti-TNF-alpha scFv antibody in Escherichia coli. Adv Pharm Bull 5(4):455-461. 10. 15171/apb.2015.062

Singh A, Upadhyay V, Panda AK (2015a) Solubilization and refolding of inclusion body proteins. Methods Mol Biol 1258:283-291. https:// doi.org/10.1007/978-1-4939-2205-5 15
Singh A, Upadhyay V, Upadhyay AK, Singh SM, Panda AK (2015b) Protein recovery from inclusion bodies of Escherichia coli using mild solubilization process. Microb Cell Factories 14(1):41. https://doi.org/10.1186/s12934-015-0222-8

Strandberg L, Enfors SO (1991) Factors influencing inclusion body formation in the production of a fused protein in Escherichia coli. Appl Environ Microbiol 57(6):1669-1674

Striedner G, Cserjan-Puschmann M, Potschacher F, Bayer K (2003) Tuning the transcription rate of recombinant protein in strong Escherichia coli expression systems through repressor titration. Biotechnol Prog 19(5):1427-1432. https://doi.org/10.1021/ bp034050u

Upadhyay AK, Murmu A, Singh A, Panda AK (2012) Kinetics of inclusion body formation and its correlation with the characteristics of protein aggregates in Escherichia coli. PLoS One 7(3):e33951. https://doi.org/10.1371/journal.pone.0033951

Vera A, Gonzalez-Montalban N, Aris A, Villaverde A (2007) The conformational quality of insoluble recombinant proteins is enhanced at low growth temperatures. Biotechnol Bioeng 96(6):1101-1106. https://doi.org/10.1002/bit.21218

Villaverde A, Corchero JL, Seras-Franzoso J, Garcia-Fruitos E (2015) Functional protein aggregates: just the tip of the iceberg. Nanomedicine (Lond) 10(18):2881-2891. https://doi.org/10.2217/ nnm. 15.125

Warner JB, Lolkema JS (2003) CcpA-dependent carbon catabolite repression in bacteria. Microbiol Mol Biol Rev 67(4):475-490. https://doi. org/10.1128/MMBR.67.4.475-490.2003

Wechselberger P, Sagmeister P, Herwig C (2013) Real-time estimation of biomass and specific growth rate in physiologically variable recombinant fed-batch processes. Bioprocess Biosyst Eng 36(9):12051218. https://doi.org/10.1007/s00449-012-0848-4

Wurm DJ, Veiter L, Ulonska S, Eggenreich B, Herwig C, Spadiut O (2016) The E. coli pET expression system revisited-mechanistic correlation between glucose and lactose uptake. Appl Microbiol Biotechnol 100(20):8721-8729. https://doi.org/10.1007/s00253016-7620-7

Wurm DJ, Hausjell J, Ulonska S, Herwig C, Spadiut O (2017) Mechanistic platform knowledge of concomitant sugar uptake in Escherichia coli BL21(DE3) strains. Sci Rep 7:45072. https://doi. org/10.1038/srep45072

Yamaguchi H, Miyazaki M (2014) Refolding techniques for recovering biologically active recombinant proteins from inclusion bodies. Biomol Ther 4(1):235-251. https://doi.org/10.3390/biom4010235

Zhang Z, Kuipers G, Niemiec Ł, Baumgarten T, Slotboom DJ, de Gier JW, Hjelm A (2015) High-level production of membrane proteins in E. coli BL21(DE3) by omitting the inducer IPTG. Microb Cell Factories 14(1):142. https://doi.org/10.1186/s12934-015-0328-z 